\title{
Ser du bakenfor?
}

\section{Forskning og statistikk er viktig} når vi snakker om mobbing, men min oppfatning er at om vi utelukkende snakker om alvorlige, mellommenneskelige temaer på en overordnet måte, skaper det en distanse til realitetene og menneskene det gjelder. Det ønsker ikke jeg å være en formidler av.

Jeg ønsker å skape nærhet til det vi ikke forstår, det vi synes er ubehagelig og ikke tror angår oss. For når alt kommer til alt, er det slik at mobbing handler om hva vi mennesker gjør og ikke gjør. Det handler om hva du som lege velger å se og hvordan du velger å se det. Det handler om å se bakenfor magevondten, søvnproblemene, spiseforstyrrelsene og selvskadingen mange barn og unge strever med. Det handler om legens ansvar for å skape en mulighet for barn til å fortelle om hva som ligger bak de tilsynelatende uforståelige handlingene og symptomene - som selv ikke foreldrene forstår.

Mobbing er barn og unges hemmelige mareritt, og det finnes ikke den test i verden som kan bevise eller avkrefte hvor vondt de har det. Selv om det kan være vanskelig for rasjonelle voksne som liker å forholde seg til slikt det finnes en kur mot, må vi ta innover oss at det kan være mange grunner til at vi ikke får vite første gang vi foretar en undersøkelse. Mange barn er redde for å bli mobbet mer dersom de forteller om det til noen - og noen har også erfart at det stemmer i skolesammenheng. Det var lite status forbundet med å være sladrehank da vi vokste opp, og slik er det for barn i dag også.

Noen opplever å ha trusler hengende over seg hvis de skulle finne på å sladre til noen. Dessuten er det et faktum at alle $\emptyset n s k e r$ å være et vellykket barn og ikke vil bekymre foreldrene sine med å være en «taper» og vise dem at de har fått et upopulært barn. Mange barn og unge bærer også på en sterk skam over ikke å klare seg selv og plukker forbausende tidlig opp voksnes - og noen legers - holdninger om at mobbeofre selv må ta en del av skylden, at de må tåle «litt»og med fordel kan bli litt likere de andre som er mer tilpasningsdyktige (les: de populære barna). Dette er holdninger som bidrar tilå lukke barn som trenger å åpne seg.

\section{Hvordan kan du som lege møte et barn} som er blitt eller blir mobbet?

- Signaliser at du ønsker å finne ut hva som har skjedd, men unngå lange forhør. Ikke konkluder og fastslå sannheter $f ø r$ barnet selv opplever at det har fått sagt det som er viktig

- Følg barnets tempo - ikke vær styrt av ditt eget behov for å vite eller av at du har dårlig tid. De færreste barn ønsker å være til bry og lar da heller være å si noe - av hensyn til deg

- La barnet foreslå tiltak og løsninger for å redusere følelsen av maktesløshet. Nei, man kan ikke sende mobberen eller foreldrene til månen, men barn har ofte mange kloke tanker om små endringer som kan gjøre situasjonen litt lettere

- Ikke lov noe du ikke kan holde. Som lege i kontakt med barn kan man, selv om man er profesjonell, bli svært beveget og få sterk trang til å hjelpe og beskytte. Ikke lov et barn som lider betydelig overlast at akkurat mobbingen kan forbli mellom dere. Mobbingen må løses i barnets nettverk. Lov ikke at de aldri skal oppleve dette igjen, si heller at du vil gjøre alt du som lege kan for at de som kan hjelpe til, skal gjøre jobben sin

\section{Verdien av å lytte og evnen til} å se bakenfor det du ikke forstår Så i stedet for statistikk som forteller deg om omfanget av barn som utvikler depresjoner, spiseforstyrrelser, søvnproblemer og selvskading som følge av mobbing, tillater jeg meg å be om at du tar deg tid til å se bakenfor det du ikke forstår.

Kanskje finner du et barn med en historie det er verdt å lytte til. Et barn som blir eller er blitt mobbet og som følge av dine gode, empatiske spørsmål endelig åpner seg. Det vil i så fall gjøre deg til den ene, viktige voksenpersonen - og legen - som bringer håp om at livet kan bli godt og at barnet ikke må stå i dette alene.

Du er viktigere enn du tror.

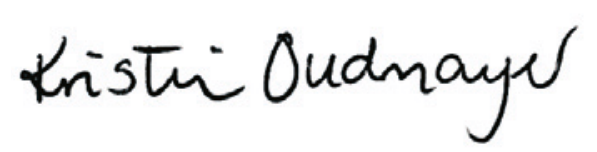

